\title{
Hepatitis C Treatment: current and future perspectives
}

\author{
Saira Munir ${ }^{\dagger}$, Sana Saleem ${ }^{\dagger}$, Muhammad Idrees $^{*}$, Aaliyah Tariq, Sadia Butt, Bisma Rauff, Abrar Hussain \\ , Sadaf Badar, Mahrukh Naudhani, Zareen Fatima, Muhmmad Ali, Liaqat Ali, Madiha Akram, Mahwish Aftab, \\ Bushra Khubaib, Zunaira Awan
}

\begin{abstract}
Hepatitis $C$ virus (HCV) is a member of Flaviviridae family and one of the major causes of liver disease. There are about 175 million HCV infected patients worldwide that constitute 3\% of world's population. The main route of HCV transmission is parental however $90 \%$ intravenous drug users are at highest risk. Standard interferon and ribavirin remained a gold standard of chronic HCV treatment having 38-43\% sustained virological response rates. Currently the standard therapy for HCV is pegylated interferon (PEG-INF) with ribavirin. This therapy achieves 50\% sustained virological response (SVR) for genotype 1 and $80 \%$ for genotype $2 \& 3$. As pegylated interferon is expensive, standard interferon is still the main therapy for HCV treatment in under developed countries. On the other hand, studies showed that pegylated IFN and RBV therapy has severe side effects like hematological complications. Herbal medicines (laccase, proanthocyandin, Rhodiola kirilowii) are also being in use as a natural and alternative way for treatment of HCV but there is not a single significant report documented yet. Best SVR indicators are genotype 3 and $2,<0.2$ million $\mathrm{IU} / \mathrm{mL}$ pretreatment viral load, rapid virological response (RVR) rate and age $<40$ years. New therapeutic approaches are under study like interferon related systems, modified forms of ribavirin, internal ribosome entry site (HCV IRES) inhibitors, NS3 and NS5a inhibitors, novel immunomodulators and specifically targeted anti-viral therapy for hepatitis $C$ compounds. More remedial therapies include caspase inhibitors, anti-fibrotic agents, antibody treatment and vaccines.
\end{abstract}

\section{Background}

Hepatitis $\mathrm{C}$ virus (HCV) is a meticulous factor of liver disease and one of the most important health issues worldwide [1,2]. Hepatitis C has approximately 175 million Global Disease Burden which represent almost 3\% of the whole population in the world, each year 3 to 4 million new patients with $\mathrm{HCV}$ are diagnosed. $\mathrm{HCV}$ remains endemic in many countries of the world [3-5]. Statistics based on general healthy population revealed that $\mathrm{HCV}$ has $5.3 \%$ seroprevalence in Pakistan, $2.2 \%$ in Turkey and $7.7 \%$ in Zimbabwe [6-8]. Hepatitis $C$ virus infection is not a main factor of mortality in the first decade of infection [9]. Even though, the biological aspects of $\mathrm{HCV}$ are revealed to a great extent in recent years, an absolute therapy of hepatitis $C$ remains

\footnotetext{
* Correspondence: idrees.khan96@yahoo.com

† Contributed equally

Division of Molecular Virology \& Molecular Diagnostics, National Centre of Excellence in Molecular Biology, University of the Punjab, Lahore, Pakistan
}

problematic in a large majority of patients [10] and about 50\% HCV patients does not attain sustained virological Responses [11-13].

A few years back, it was not easy to study HCV in invitro because there was no proficient system present but fortunately Heller et al got success in establishing in vitro model of $\mathrm{HCV}$ virions. This system proves good for high level production and secretion of HCV virions hence this system expands the scope of tools present for HCV study [14,15]. Many patients remain asymptomatic for years and are only detected on health screening or at the time of blood transfer [16]. Peg. INF and ribavirin therapy is still the therapy of choice for HCV patients besides having many side affects $[17,12]$. As HCV is mainly a chronic disease and progress very slowly therefore persistent infection is a typical characteristic of disease which can be found in approximately $75 \%$ patient at primarily stage. Prospective studies conducted on natural history suggest that $\mathrm{HCV}$ take almost 20 years to
C Biomed Central 
develop cirrhosis and only $20 \%$ of cirrhotic patient can develop Hepatocellular Carcinoma (HCC) after 40 years of preliminary infection $[18,10]$.

\section{HCV genotypes and treatment response}

Patients with different HCV genotypes react in a different way to alpha interferon because genotype is one of the strongest prognostic aspects of sustained virological response [19,20]. This clinical importance of HCV genotype was revealed by clinical studies based on interferon treatment response account [5]. Patients show more sustained virological response when suffered from $\mathrm{HCV}$ genotype 2 and 3 as compared to HCV infected persons of genotype1 [6]. Patients infected with HCV genotype 2 and 3 show $65 \%$ SVR and patients with HCV genotype 1 show 30\% Sustained Virological Response (SVR) [7,8]. Thus genotype of patients must not be over looked when giving standard interferon therapy. Different ethnic groups respond differently to standard therapy of HCV and hence there is variation in Early Treatment Response (ETR) and SVR rates [21].

\section{Mechanism of Pathogenesis and interferon resistance}

Now a number of mechanisms associated with escape of the pathogen from the host's immune response, hepatocyte damage and molecular oncogenesis of hepatocellular carcinoma have been elucidated. Inefficient clearance of virus from patient's body is basically due to the hyper-variability of virus envelope protein that enables $\mathrm{HCV}$ to neutralize antibody [22,23]. Once the virus enters the hepatocytes through receptor mediated endocytosis and starts replication, it initiate damaging of hepatocyte, the major component of which is through the host's own immune response [24,23]. Interferon is the most potent natural weapon of the host against intra-cellular viral infection. $\mathrm{HCV}$, however, owing to intricate actions of its genomic proteins is equipped with ability to evade the natural interferon-mediated clearance. $\mathrm{HCV}$ core protein has been reported to decrease the robustness of the host's immune response by decreasing transcription of interferon induced antiviral genes [25,23]. HCV NS3/4A protease also has been concerned in inhibiting the interferon amplification loop which otherwise results in suppression of HCV replication. Inhibition of HCV protease can reverse the effects of $\mathrm{HCV}$ infection that make protease inhibitors one of the most noteworthy potential therapeutic agents for HCV $[26,25]$.

\section{Route of transmission and treatment response}

At first, it was believed that most frequent route of transmission of $\mathrm{HCV}$ was blood transfusion and intravenous drug abuse. But recent epidemiological studies suggest further routes of transmission [27]. The main route of $\mathrm{HCV}$ transmission is parental. However 90\% intravenous drug users are at highest risk of getting $\mathrm{HCV}$ infection such as those who require multiple blood transfusions and blood products (hemophiliacs) or those who go through major surgery $[28,29]$. Unlike HBV, HCV infection transfer less frequently by sexual or intimate contact (0.4 to 3\%). Domestic contacts are also at low risk [30]. Almost 5\% HCV infections are caused by needle stick injury $[29,30] .3 \%$ to $5 \%$ infants acquire $\mathrm{HCV}$ from infected mother by perinatal transmission [31]. HCV is present in saliva and milk but transfer of HCV infection through breast milk has not been reported [32,33].

Community barbershops also play a key role in HCV transmission in under development countries [27]. Some other reported risk factors of disease transmission are dental and surgical treatments, circumcision, ear piercing, tattooing and dialysis [34-36]. In a study conducted on 3351 patients of HCV in Pakistan it has been documented that more than $70 \%$ hepatitis $\mathrm{C}$ infections are spread in hospitals by the use of same needle several times and major or minor operations that are extremely frequent in Pakistan. Globally reuse of needles is also common source of transmission [37]. Studies show that RVR and SVR are independent of transmission routes of $\mathrm{HCV}$.

\section{Base line diagnosis}

Detection of anti HCV by ELISA is the initial step in diagnosis of $\mathrm{HCV}$ infection and it is more than $99 \%$ sensitive and specific [38]. PCR is the second main step in the analysis of chronic HCV infection and exposure of virus is usually detectable within 7 to 21 days $[39,40]$. Liver biopsy is also an important parameter in diagnosis of chronic $\mathrm{HCV}$ infection but as persons infected with genotype $2 / 3$ respond well to standard therapy, treatment can be started without liver biopsy [40].

\section{Therapy for HCV infection}

Chronic HCV is treated with a glycoprotein commonly known as interferon (INF) alpha and it is considered the backbone of therapy because it efficiently increases the immune response against virus [41]. Afterward interferon plus ribavirin become a gold standard (3 MIU thrice weekly along with ribavirin 800 to1200 $\mathrm{mg}$ per day). This treatment enhances SVR rate up to 38$43 \%$. As SVR greatly depend on HCV genotype so genotype 1 needs treatment for 48 weeks to achieve SVR of $29 \%$ and genotype 2 and 3 needs treatment up to 24 weeks to attain SVR rate of $66 \%$ [42]. Currently the regular treatment of HCV is pegelated interferon (PEGINF) in combination with ribavirin. This therapy achieves SVR of about $50 \%$ for genotype 1 and $80 \%$ for genotype 2 \& 3 [43]. 
There are two types of pegylated interferon; PEG-IFNalpha-2a and PEG-IFN-alpha-2b. These are dissimilar only by size and configuration of the polyethylene glycol molecules that has binding sites for interferon. The functioning of these two formulated interferon not compared still but both are equally good for HCV treatment [44].

Current HCV therapy for genotypes $2 \mathrm{a}$ to $2 \mathrm{~b}, 3 \mathrm{a}$ to $3 \mathrm{~d}, 5 \mathrm{a}, 6 \mathrm{a}$ and mixed genotypes infected patients is 3 subcutaneous injections of $3 \mathrm{MU}$ of recombinant interferon alpha and ribavirin (10 $\mathrm{mg}$ per day per $\mathrm{kg}$ body weight) in one week for 6 months. Individuals infected from HCV genotype 1a to 1c, 4 and mixture of 1 and 4 $\mathrm{HCV}$ genotypes should receive three $3 \mathrm{MU}$ subcutaneous injections of recombinant IFN alpha and ribavirin that are given orally (for individuals with $\leq 75 \mathrm{~kg}$ body weight) require $1,000 \mathrm{mg}$ per day, for patients with $>75$ $\mathrm{kg}$ body mass require $1,200 \mathrm{mg}$ per day) in a week for total 48 weeks [45].

Conventional interferon (C-INF) therapy is used for $\mathrm{HCV}$ treatment in poor countries because of financial reasons and Pakistan Society of Gastroenterology and GI Endoscopy also recommend the use of C-INF therapy for HCV genotype 3 in Pakistan [46,40]. In under developed and developing countries including Pakistan, pegylated interferon therapy is beyond the reach of common poor patients $[47,40]$. In 2001, FDA permitted two kinds of PEG-INF (i) PEG-INF Alpha 2a (40 KD) and (ii) PEG-INF Alpha 2b (12 KD). These are administered only once a week because they have long half life of plasma (almost 10 times) in comparison with conventional INF. Liver primarily metabolizes PEG-INF Alpha $2 \mathrm{a}$ and kidney excretes out PEG-INF Alpha 2b. Recent studies and clinical trials confirmed that SVR rates could be increased by the using mono therapy with PEG-INF 2a or PEG-INF 2b in comparison with conventional interferon $[48,40]$.

\section{Limitations of Recent HCV Therapy}

It has been reported that $40 \%$ to $50 \%$ patients with $\mathrm{HCV}$ genotypes 1 and or 4 early attain SVR in comparison with $80 \%$ patients infected with genotypes 2 and or 3 $[4,49]$. However PEG-IFN and ribavirin treatment has severe side effects. Major complications of standard interferon and ribavirin therapy are anemia, cytopenias, neutropenia and thrombocytopenia as elucidated in table 1.

Novel types of interferon alpha (albinterferon) are under study; these might be very suitable anti-viral therapy because these can be given just once or twice a month as compared to standard PEG-IFN therapy $[4,49]$. Taribavirin, a recently introduced drug, is tested in various randomized trials that show low efficacy but also has a few complains of anemia and the side effects are easily manageable $[50,4]$. There are also several side affects associated with conventional interferon and ribavirin therapy including Influenza like sign and symptoms. For example headache, myalgias or arthralgias, fever, anorexia, nausea or vomiting, fatigue, abdominal pains, insomnia, suicide attempt, pruritis, anaemia, redness at injection site, dry skin, leucopoenia, irritability, thrombocytopoenia, anxiety, psychosis and laryngitis [51].

\section{Herbal treatment}

There is no effective vaccine developed or excellent drug available for the treatment of HCV. Standard INF therapy in combination with ribavirin show sustained virological response with efficacy of not more than $50 \%$, therefore most of the patients try herbal medicine and conventional medicine all over the world particularly in poor countries. Laccase are largely used as herbal medicine that is extracted from oyster mushroom (Pleurotus ostreatus). Studies showed that laccase is proficient in inhibiting the HCV replication rate [52] however the mechanism of action of this medicine is not known.

Herbal treatment can open a natural and alternative way for treatment of $\mathrm{HCV}$. As Hepatitis $\mathrm{C}$ virus infects liver and this infection requires two or more decades to extend into substantial disease, a nutritional supplement might facilitate to decrease or stop disease development. More recent studies regarding herbal treatment provoke a hope for HCV patient that is based on a chemical known as proanthocyandin, extracted from blueberry leaves. It has been reported that proanthocyandin can stop HCV replication in infected patients [53]. According to another study rhizomes of the Chinese medicinal herb Rhodiola kirilowii may also act as possible inhibitor of $\mathrm{HCV}$ [54].

\section{Factors affecting treatment response}

Treatment response is better in patient of less than 40 years of age in comparison with elderly. Young females respond well to the treatment. High intensity of viremia is related with deprived response. Immunodeficiency, excessive use of alcohol and co-infection with HIV or HBV, all harmfully cause the result to HCV infection $[55,16]$.

$\mathrm{HCV}$ therapy is not suitable for people suffering from severe HCV related cirrhosis, undergone organ transplant, children of $<3$ years and specific contraindication to the medication. Interferon causes severe side effect includes, anxiety, irritability personality changes, even suicide, depression or acute psychosis. Ribavirin side effect included anemia, renal dysfunction of coronary artery. Fetal abnormality and fatality are important side effects of ribavirin, a well-known teratogen.

Due to the distinctive character of the virus to develop vaccine against $\mathrm{HCV}$ leftovers, a disappointment has been seen due to its high mutation rate. It has already 
Table 1 Contraindications situations for pegylated interferon and ribavirin therapy

\begin{tabular}{|c|c|}
\hline Contraindications levels & Situations \\
\hline \multirow[t]{6}{*}{ No more contraindications } & - Regular alanine aminotransferase \\
\hline & - Methadone maintenance \\
\hline & - Anemia/thrombocytopenia and neutropenia \\
\hline & - Restricted seizure \\
\hline & - Age more than 65 years \\
\hline & - Excess use of alcohol \\
\hline \multirow[t]{5}{*}{ Virtual contraindications } & - Depression \\
\hline & - Psychosis \\
\hline & - Autoimmune disorder \\
\hline & - Drug abuser \\
\hline & - Renal failure (with dialysis) \\
\hline \multirow[t]{4}{*}{ Tough although not general contraindications } & -Alcohol use \\
\hline & -Coronary artery disorder \\
\hline & - Hepatic decompensation \\
\hline & - Transplantation of solid organ (except liver) \\
\hline General contraindications & - Pregnancy \\
\hline
\end{tabular}

been reported that the rate of $\mathrm{HCV}$ reproduction is high and the error-prone polymerase causes mutation continuously. The high HCV replication rate provides sufficient chance of mutation that occurs in the viral population inside an infected person. Production of virus has been estimated at $10^{12}$ (one trillion) new $\mathrm{HCV}$ virions per day [56]. Studies on chronically infected $\mathrm{HCV}$ patients show that rate of mutation in HCV genome has been approximately 0.001 substitutions per genomic site in one year. Such high rate of mutation could result into 8-18 mutations within the RNA of 9.6 $\mathrm{kb}$ genomic size. It has also been reported that envelop protein E2 has highly mutated sites known as hypervariable region HVR1. High variation in E2 causes immune escape mutants of the virus as of the neutralizing antibodies and therefore describes the constant viremia. In addition to E2 gene, P7 region has also been shown with increased variability [16].

\section{Future perspectives}

New therapeutic approaches are under study like interferon related systems, modified forms of ribavirin, siRNA, internal ribosome entry site (IRES) inhibitors, NS3 and NS5a inhibitors and novel immunomodulators. These are particularly for those patients who show low SVR rate by traditional therapies. More remedial therapies include antifibrotic agents, caspase inhibitors and antibody treatment and vaccines. Particularly targeted antiviral compounds like specifically targeted anti-viral therapy for hepatitis C' (STAT-C) compounds are now under study by scientists that are used along with standard interferon therapy. Reports confirm improved SVR rate at least in HCV genotype 1 patients. Further studies are required to confirm its significance in the clearance of HCV RNA if used as a single therapy without interferon and ribavirin $[57,58]$.

\section{Conclusion}

Currently chronic HCV treatment consists of pegelated interferon alpha and a nucleoside analogue ribavirin for 3 to 18 months. However several side effects are associated with this treatment. New therapeutic approaches are under study and recent clinical trials are being focused on inhibitors of HCV NS3 and NS5a RNA polymerase. Parameters that increase SVR rate for $\mathrm{HCV}$ are genotype 2 and 3 , age $<40$ years and low viral load before treatment.

\section{Abbreviations}

HCV: hepatitis C virus; PEG-INF: pegylated interferon; RVR: rapid virological response; SVR: sustained virological response; RBV: ribavirin; ETR: end of treatment response; ELISA: enzyme linked immunosorbant assay; PCR: polymerase chain reaction; MIU: million international units; SDINF: standard interferon; HVR: hiper variable region; IRES: internal ribosome entry site; STAT-C: specifically targeted anti-viral therapy for hepatitis C.

\section{Authors' contributions}

SM and SS reviewed the literature, and wrote the manuscript. Ml edited the manuscript. AT, SB, BR, AH, SB, ZA, MN, ZF, MA, LA, MA, MA, BK, helped SM \& SS in literature review. All the authors read and approved the final manuscript.

\section{Competing interests}

The authors declare that they have no competing interests.

Received: 22 September 2010 Accepted: 1 November 2010 Published: 1 November 2010

\section{References}

1. Asselah T, Estrabaud E, Bieche I, Lapalus M, De Muynck S, Vidaud M, Saadoun D, Soumelis V, Marcellin P: Hepatitis C: viral and host factors associated with non-response to pegylated interferon plus ribavirin. Liver Int 2010, ISSN 1478-3223. 
2. Alter MJ: Epidemiology of hepatitis C virus infection. World I Gastroenterol 2007, 13(17):2436-41.

3. Butt AA: Hepatitis C virus infection: the new global epidemic. Expert Rev Anti Infect Ther 2005, 3:241-9.

4. Soriano V, Peters GMarion, Zeuzem S: New Therapies for Hepatitis C Virus Infection. Clinical Infectious Diseases 2009, 48:313-20.

5. Koziel M, Peters M: Viral hepatitis in HIV infection. N Engl J Med 2007, 356:1445-54

6. Demirtürk N, Demirdal T, Toprak D, Altindiș M, Aktepe OC: Hepatitis B and $C$ virus in West-Central Turkey: Seroprevalence in healthy individuals admitted to a university hospital for routine health checks. Turk $J$ Gastroenterol 2006, 17:267-72

7. Gangaidzo IT, Moyo VM, Khumalo H, Saungweme T, Gomo Z, Rouault T, Gordeuk VR: Hepatitis C virus in Zimbabwe. Cent Afr J Med 1997, 43:122-5.

8. Khokhar N, Gill ML, Malik GJ: General seroprevalence ofhepatitis C and hepatitis B virus infections in population. J Coll Physicians Surg Pak 2004, 14:534-6.

9. Harris HE, Ramsay ME, Andrews N, Eldridge KP: Clinical course of hepatitis C virus during the first decade of infection: cohort study. BMJ 2002, 324:1-6.

10. Jawaid A, Khuwaja AK: Treatment and vaccination for hepatitis C: present and future. J Ayub Med Coll Abbottabad 2008, 20(1):129-33.

11. Manns MP, McHutchison JG, Gordon SC, Rustgi VK, Shiffman M, Reindollar R, Goodman ZD, Koury K, Ling M, Albrecht JK: Peginterferon alfa- $2 \mathrm{~b}$ plus ribavirin compared with interferon alfa- $2 \mathrm{~b}$ plus ribavirin for initial treatment of chronic hepatitis C: a randomised trial. Lancet 2001, 358(9286):958-965.

12. Baldick CJ, Wichroski MJ, Pendri A, Walsh AW, Fang J, Mazzucco CE, Pokornowski KA, Rose RE, Eggers BJ, Hsu M, Zhai W, Zhai G, Gerritz SW, Poss MA, Meanwell NA, Cockett MI, Tenney DJ: A novel small molecule inhibitor of hepatitis C virus entry. PLoS Pathog 2010, 6(9), pii: e1001086.10.1371/journal.ppat.1001086.

13. National Institutes of Health Consensus Development Conference Statement: Management of hepatitis C 2002 (June 10-12, 2002). Gastroenterology 2002, 123(6):2082-2099.

14. Heller T, Saito S, Auerbach J, Williams T, Moreen TR, Jazwinski A, Cruz B, Jeurkar N, Sapp R, Luo G, Liang TJ: An in vitro model of hepatitis C virion production. Proc Natl Acad Sci USA 2005, 102:2579-83.

15. Sheehy P, Mullan B, Moreau I, Kenny-Walsh E, Shanahan F, Scallan M, Fanning LJ: In vitro replication models for the hepatitis $C$ virus. J Viral Hepa 2007, 14(1):2-10.

16. Contreras AM, Ochoa-Jiménez RJ, Celis A, Méndez C, Olivares L, Rebolledo CE, Hernandez-Lugo I, Aguirre-Zavala Al, Jiménez-Méndez R, Chung RT: High antibody level: an accurate serologic marker of viremia in asymptomatic people with hepatitis C infection. Transfusion 2010, 50(6):1335-43

17. Fried MW, Shiffman ML, Reddy KR, Smith C, Marinos G, Gonçales FL Jr, Häussinger D, Diago M, Carosi G, Dhumeaux D, Craxi A, Lin A, Hoffman J, Yu J: Peginterferon alfa-2a plus ribavirin for chronic hepatitis $C$ virus infection. N Engl J Med 2002, 347(13):975-982.

18. Seeff LB: Natural history of hepatitis C. Am J Med 1999, 107(6B):10S-15S.

19. Idrees $M$, Riazuddin S: Frequency distribution of hepatitis $C$ virus genotypes in different geographical regions of Pakistan and their possible routes of transmission. BMC Infectious Diseases 2008, 8:69.

20. Zein NN, Rakela J, Krawitt EL, Reddy KR, Tominaga T, Persing DH: Hepatitis $C$ virus genotypes in the United States: epidemiology, pathogenicity, and response to interferon therapy. Ann Intern Med 1996, 125:634-639.

21. Idrees $M$, Riazuddin S: A study of best positive predictors for sustained virologic response to interferon alpha plus ribavirin therapy in naive chronic hepatitis C patients. BMC Gastroenterology 2009, 9:5.

22. Brown RJ, Juttla VS, Tarr AW, Finnis R, Irving WL, Hemsley S, Flower DR, Borrow $P$, Ball JK: Evolutionary dynamics of hepatitis $C$ virus envelope genes during chronic infection. J Gen Virol 2005, 86(7):1931-42.

23. Choi J, James JHO: Mechanisms of Liver Injury. III. Oxidative stress in the pathogenesis of hepatitis C virus. J Physiol Gastrointest Liver Physiol 2006, 290:G847-G851.

24. Nelson DR: The immunopathogenesis of hepatitis $C$ virus infection. Clin Liver Dis 2001, 5:931-53.

25. De Lucas S, Bartolome J, Carreno V: Hepatitis $C$ virus core protein downregulates transcription of interferon-induced antiviral genes. J Infect Dis 2005, 191:93-9.
26. Karayiannis $P$ : The hepatitis $C$ virus NS3/4A protease complex interferes with pathways of the innate immune response. J Hepatol 2005, 43:743-5.

27. Raja1 NS, Janjua KA: Epidemiology of hepatitis $C$ virus infection in Pakistan. J Microbiol Immunol Infect 2008, 41:4-8.

28. Khokhar N, Gill ML, Malik KJ: General seroprevalance of Hepatitis C \& hepatitis B virus infections in Pakistan. J Coll Phy Surg Pak 2004, 14(9):534-15.

29. Kiyosawa K, Sodeyama T, Tanaku E: Hepatitis C in hospital employees with needle stick injuries. Ann intern Med 1991, 115:367-9.

30. Din RU, Kamal A, Khan HU: Hepatitis C. Gomal Journal of Medical Sciences 2004, 2(1):27-29.

31. Papanastasiou DA, Spiliopoulou I, Katinakis S, Karana-Ginopoulou A, Repanti M: Lack of transmission of hepatitis $\mathrm{C}$ in household contacts of children with homozygous beta-thalassaemia. Acta Haematol 1997, 97(3):168-73.

32. Ohto H, Terazawa S, Sasaki N, Sasaki N, Hino K, Ishiwata C, Kako M, Ujiie N, Endo C, Matsui A: Transmission of hepatitis C virus from mothers to infants. N Engl J Med 1994, 330:744-750

33. Ogasawara S, ki Kasai Kagem: Hepatitis C virus RNA in saliva and breast milk of Hepatitis C carriers. Lancet 1993, 341:561.

34. Muhammad N, Jan MA: Frequency of hepatitis " $\mathrm{C}$ " in Buner, NWFP. J Coll Physicians Surg Pak 2005, 15:11-4.

35. Butt AK, Khan AA, Khan SY, Sharea I: Dentistry as a possibl route of hepatitis C transmission in Pakistan. Int Dent J 2003, 53:141-4.

36. Khokhar N, Aijazi I, Gill ML: Spectrum of hepatocellular carcinoma at Shifa International Hospital, Islamabad. J Ayub Med Coll Abbottabad 2003, 15:1-4.

37. Romano CM, de Carvalho-Mello IM, Jamal LF, de Melo FL, lamarino A, Motoki M, Pinho JR, Holmes EC, de Andrade Zanotto PM: VGDN Consortium: Social networks shape the transmission dynamics of hepatitis C virus. PLoS One 2010, 5(6), e11170.10.137/journal.pone.

38. Iancu LS: Diagnostic strategies in Hepatitis C virus infection. Rev Med Chir Soc Med Nat lasi 2001, 105(1):37-42.

39. Gretch DR: Diagnostic tests for Hepatitis C. Hepatology 1997 299(1):435-475.

40. Castillo I, Bartolomé J, Quiroga JA, Barril G, Carreño V: Diagnosis of occult hepatitis C without the need for a liver biops. J Med Virol 2010, 82(9):1554-9.

41. Caritter RL, Emerson SS: Therapy of hepatitis - meta analysis of interferon alpha 2b trials. Hepatology 1997, 26(3,1):835-85

42. Poynard T: Randomized trial of interferon alpha-2b plus ribavirin for 48 weeks versus interferon alpha- $2 \mathrm{~b}$ plus placebo for 48 weeks for the treatment of chronic hepatitis-C virus. Lancet 1998, 351:1426.

43. Fox RK, Wright TL: Viral Hepatitis. Current diagnosis and treatment. Gastroenterology 2003, 2:446-562.

44. Sherman M, Shafran S, Burak K, Doucette K, Wong W, Girgrah N, Yoshida E, Renner E, Wong P, Deschênes M: Management of chronicnhepatitis C: Consensus guidelines. Can J Gastroenterol 2007, 21(Suppl C):25C-34C.

45. Idrees M, Riazuddin S: A study of best positive predictors for sustained virologic response to interferon alpha plus ribavirin therapy in naive chronic hepatitis C patients. BMC Gastroenterol 2009, 9:5.

46. Hamid S, Umar M, Alam A, Siddiqui A, Qureshi H, Butt J: PSG consensus statement on management of hepatitis C virus infection-2003. J Pak Med Assoc 2004, 54:146-150.

47. Zuberi Faiyaz Bader, Zuberi Faiyaz Faisal, Memon Ali Sajjad, Qureshi Hafeez Muhammad, Ali Zafar Sheikh, Salahuddin Afsar: Sustained virological response based on rapid virological response in genotype-3 chronic hepatitis $C$ treated with standard interferon in the Pakistani population. World J Gastroenterol 2008, 14(14):2218-2221.

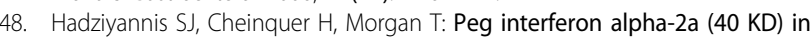
combination with ribavirin -Efficacy and safety results from phase 3, randomized double blind, multicenter study examining effect of duration and ribavirin dose. J Hepatol 2002, 36(1):3.

49. Zeuzem S, Yoshida E, Benhamou Y: Sustained virologic response rates with albinterferon alfa- $2 \mathrm{~b}$ plus ribavirin treatment in IFN-naïve chronic hepatitis C genotype 1 patients. Hepatology 2007, 46(I):317A.

50. Gish R, Arora S, Rajender K, David RN, Christopher OB, Xu Y: Murphy B: Virological response and safety outcomes in therapy-naive patients treated for chronic hepatitis $C$ with taribavirin or ribavirin in combination with pegylated interferon alfa-2a: a randomized, phase 2 study. J Hepatol 2007, 47:51-9. 
51. Orito E, Mizoguchi N: Hepatitis-C virus serotype 2 response more favourably to interferone; a therapy. J Hepatol 1994, 21:130-2.

52. El-Fakharany EM, Haroun BM, Ng TB, Redwan ER: Oyster mushroom laccase inhibits hepatitis $C$ virus entry into peripheral blood cells and hepatoma cells. Protein Pept Lett 2010, 17(8):1031-9.

53. Takeshita M, Ishida YO, Akamatsu E, Ohmori Y, Sudoh M, Uto H, Tsubouchi H, Kataoka H: Proanthocyanidin from Blueberry Leaves Suppresses Expression of Subgenomic Hepatitis C Virus RNA. journal of biological chemistry 2009, 284(32):21165-21176.

54. Zuo G, Li Z, Chen L, Xu X: Activity of compounds from Chinese herbal medicine Rhodiola kirilowii (Regel) Maxim against HCV NS3 serine protease. Antiviral Res 2007, 76(1):86-92.

55. Welfman M, Brotodihardjo A, Crewe E: Coinfection with hepatitis B and C, $C$ and $D$ viruses result in severe chronic liver disease and responds poorly to interferon. J Vviral Hept 1995, 2:39-45.

56. Neumann AU, Lam NP, Dahari H, Gretch DR, Wiley TE, Layden TJ, Perelson AS: Hepatitis C viral dynamics in vivo and the antiviral efficacy of interferon-alpha therapy. Science 1998, 282:103-7.

57. Lange CM, C. Sarrazin, Zeuzem S: specifically targeted anti-viral therapy for hepatitis C - a new era in therapy. Aliment Pharmacol Ther 2010, 32:14-28.

58. Kapadia SB, Brideau-Andersen A, Chisari FV: Interference of hepatitis $C$ vius RNA replication by short interfering RNAs. Proc Natl Acad Sci USA 2003, 100(4):2014-8.

doi:10.1186/1743-422X-7-296

Cite this article as: Munir et al:: Hepatitis C Treatment: current and future perspectives. Virology Journal 2010 7:296.

\section{Submit your next manuscript to BioMed Central} and take full advantage of:

- Convenient online submission

- Thorough peer review

- No space constraints or color figure charges

- Immediate publication on acceptance

- Inclusion in PubMed, CAS, Scopus and Google Scholar

- Research which is freely available for redistribution

Submit your manuscript at www.biomedcentral.com/submit
Ciomed Central 